\title{
FREQUENCY OF OBSTRUCTIVE PATTERN ON SPIROMETRY IN ASYMPTOMATIC CHRONIC SMOKERS.
}

\footnotetext{
1. MBBS, FCPS

Senior Registrar Pulmonology

Rawal Institute of Health Sciences Islamabad.

2. MBBS, Ph.D

Associate Professor Physiology Quaid-e-Azam Medical College, Bahawalpur.

3. MBBS, FCPS

Assistant Professor and Head Pulmonology

Sahiwal Medical College Sahiwal.

4. MBBS, M.Phil

Assistant Professor Physiology

Sahiwal Medical College Sahiwal.

5. MBBS, M.Phil

Assistant Professor Physiology

Sahiwal Medical College Sahiwal.

6. MBBS, FCPS

Principal and Head Ophthalmology

Sahiwal Medical College Sahiwal.
}

Correspondence Address:

Dr. Zaid Umar

Department of Pulmonology

Rawal Institute of Health Sciences

Islamabad.

zaid.umar011@gmail.com

Article received on:

04/07/2020

Accepted for publication:

15/09/2020

\section{INTRODUCTION}

COPD is a severe illness which is described by

a steady decrease in respiratory capacity and wellbeing status. ${ }^{1}$ Typically patients have side effects of incessant bronchitis and emphysema. The principle manifestations incorporate windedness, cough, and sputum production. ${ }^{2}$ Patients with COPD are inclined to worsening, which represent critical dreariness and mortality and are a key determinant of wellbeing related personal satisfaction. ${ }^{3}$ Globally, starting at 2010, COPD influenced around 329 million individuals (4.8\% of the populace) and is somewhat more typical in men than women. ${ }^{4,5}$ Chronic obstructive lung disease is a main and developing reason for dismalness and mortality worldwide ${ }^{6}$, representing a gigantic monetary and social weight. Notwithstanding the distribution of rules on COPD avoidance and management ${ }^{6-8}$ the weight of the illness is expanding as the total populace ages. In 2001 COPD was the fifth essential driver of death on the planet, and it is anticipated to be third by $2020 .{ }^{9}$ Cigarette smoking is the most asserted hazard factor and stays an across the board habit. ${ }^{10}$

Smoking has unfavourable wellbeing consequences for the whole lung, influencing each part of lung structure and capacity which incorporates disabling lung barriers against contamination and causing the continued lung injury that prompts interminable obstructive aspiratory sickness. Spirometry is generally suggested as a screening technique for every single indicative individual, explicitly in subjects with a long - term hazard exposure. ${ }^{11} \mathrm{~A}$ former study showed COPD prevalence of $21.5 \%$ in asymptomatic smokers. ${ }^{12} \mathrm{~A}$ similar study in $\mathrm{CMH}$ Rawalpindi Pakistan showed COPD prevalence of $8.5 \%$ in asymptomatic smokers. ${ }^{13}$ In another study on six hundred and thirty-seven smokers without symptoms, the prevalence of COPD was found $7 \% .{ }^{14}$ Spirometric indices will be very helpful in detecting obstructive lung diseases at early 
stages which will help health care professionals to initiate treatment at early stage and improve the outcome. Spirometry-based characterization of airflow confinement and sickness seriousness as indicated by the Global Initiative for Chronic Obstructive Lung Disease (GOLD) models is picking up acknowledgment and is being utilized in epidemiological examinations since it gives target estimation of lung work. ${ }^{6}$

So, this research was conducted to determine the frequency of obstructive pattern on spirometry in asymptomatic chronic smokers in local population. On the basis of the results of study, early preventive as well as therapeutic measures can be taken in this particular population. Moreover, on the basis of this empirical evidence, our people can be encouraged to give up smoking as well. The chronic smokers were defined as the individuals with the history of at least 1 pack year history of smoking. Furthermore, a packyear is characterized as: the number of cigarettes smoked every day separated by 20 and increased by the number of years that the member smoked. Obstructive lung design (COPD) was arranged dependent on spirometry as it is known as the Gold spirometry rules for COPD6, we characterized an obstructive example as a post-bronchodilator FEV1/FVC $<70 \%$.

For this study purpose the socioeconomic status was taken as follows:

1. Poor are those with family income less than $12000 /--$ having family income extending from Rs. 12001 to 35000 rupees.

2. Rich were those with family earnings further than Rs. 35000.

\section{MATERIAL \& METHODS}

Descriptive, cross-sectional study was piloted at department of Pulmonology, Sahiwal Medical College Sahiwal from $1^{\text {st }}$ Nov, 2019 to $1^{\text {st }}$ May 2020.

Sample size was calculated by the formula.

$n=Z^{2} P(1-P) / d^{2}$

$Z=$ Standard normal variate whose value is 1.96

$\mathrm{P}=7.0 \%$ which is the prevalence of obstructive pattern (COPD) in asymptomatic chronic smokers $^{14}$. $d=3.5 \%$ which is absolute error or precision $\mathrm{n}=205$.

Non-probability, consecutive sampling technique was used.

\section{A. Inclusion Criteria}

- Chronic smokers 1 pack year or more

- Ex-Smokers who quit smoking less than 6 months ago

- Age 30-60

- Both genders.

\section{B. Exclusion Criteria}

- History of ischemic heart disease.

- Previously diagnosed cases of COPD and Asthma.

- Patients already on bronchodilators.

- Contraindications to spirometry.

Total 205 asymptomatic smokers were chosen from medical clinic staff, patients and sound volunteers. Informed consent was gotten from every member and endorsement of ethical review board was acquired. Spirometry was performed by using portable spirometer by consultant pulmonologist (at least 2 years of post-fellowship experience) and obstructive pattern (COPD) was noted as per -operational definition. All this data including the demographic data was noted on proforma (annex I).

Data was analysed through SPSS-20. We expressed quantitative variables as mean and $\mathrm{SD}$, and categorical variables such as gende, education status (illiterate/primary/middle/matric/ graduate) as frequency and percentages.

Effect modifiers like age, gender, duration of smoking, BMI, place of living, socioeconomic status and education status were stratified. Post -stratification chi square was applied to see the effect of these on COPD and $p$-value $\leq 0.05$ was taken as significant.

\section{RESULTS}

Age limit in this research was from 30 to 60 years with mean of $47.78 \pm 4.90$ years. Bulk 86 (41.95\%) were between 41 to 50 years (Table-I). 
Out of the 205 patients, 137 (66.83\%) were male and $68(33.17 \%)$ were females (Figure-l). Mean period of symptoms was $8.81 \pm 4.67$ years as shown in Table-ll. Mean height was $161.81 \pm$ $9.23 \mathrm{~cm}$. Mean weight was $78.81 \pm 5.67 \mathrm{~kg}$. Mean BMI was $26.21 \pm 5.39 \mathrm{~kg} / \mathrm{m} 2$ (Figure-II). As far as socioeconomic status of the patients is concerned, place of living and education level is shown in Table-III, IV \& V respectively.

In this study, frequency of obstructive pattern on spirometry in asymptomatic chronic smokers was found in $29(14.15 \%)$ patients as shown in Table-III.

Prevalence of obstructive pattern by means of age and gender are shown in Table-VI \& VII respectively. Table-VIII \& IX have shown the Prevalence of obstructive pattern with duration of disease and BMI respectively. Prevalence of obstructive pattern with respect to place of living was established to be statistically significant $(P=0.029) \quad$ (Table-X). Similarly prevalence of obstructive pattern in relation to socioeconomic status was also set up to be highly significant $(\mathrm{P}=0.001)$ (Table-XI). Education level in relation to obstructive pattern was statistically significant too $(P=0.021)$ (Table-XII).

\begin{tabular}{|l|c|c|}
\hline Age (in years) & No. of Patients & \%age \\
\hline $30-40$ & 39 & 19.02 \\
\hline $41-50$ & 86 & 41.95 \\
\hline $51-60$ & 80 & 39.02 \\
\hline Total & 162 & 100.0 \\
\hline
\end{tabular}

Table-l. Age frequency of patients $(n=205)$.

Mean $\pm S D=47.78 \pm 4.90$ years

\begin{tabular}{|l|c|c|}
\hline Duration of Smoking & No. of Patients & \%age \\
\hline & & \\
\hline$\leq 5$ years & 134 & 34.63 \\
\hline$>5$ years & $8.81 \pm 4.67$ years \\
\hline Mean \pm SD & \multicolumn{2}{|c|}{$\begin{array}{r}\text { S. } \\
\text { Table-II. Frequency of patients according to duration of } \\
\text { smoking } \mathbf{( n = 2 0 5 ) .}\end{array}$} \\
\hline
\end{tabular}

\begin{tabular}{|l|c|r|}
\hline Socioeconomic Status & No. of Patients & \%age \\
\hline Poor & 89 & 43.41 \\
\hline Middle & 58 & 28.29 \\
\hline Upper & 58 & 28.29 \\
\hline
\end{tabular}

Table-III. Distribution of patients according to socioeconomic status $(n=205)$.

\begin{tabular}{|l|c|c|}
\hline \multicolumn{1}{|c|}{ Place of Living } & No. of Patients & \%age \\
\hline Rural & 129 & 62.93 \\
\hline Urban & 76 & 37.07 \\
\hline
\end{tabular}

Table-IV. Distribution of patients according to place of living $(n=205)$.

\begin{tabular}{|l|c|c|}
\hline \multicolumn{1}{|c|}{ Education status } & No. of Patients & \%age \\
\hline Illiterate & 24 & 11.71 \\
\hline Primary & 29 & 14.15 \\
\hline Middle & 45 & 21.95 \\
\hline Matric & 51 & 24.88 \\
\hline Graduate & 56 & 27.32 \\
\hline
\end{tabular}

Table-V. Distribution of patients according to educations status $(n=205)$.

\begin{tabular}{|l|c|c|c|}
\hline & \multicolumn{2}{|c|}{ Obstructive COPD } & P-Value \\
\hline Age (years) & Yes & No & \\
\hline $30-40$ & $03(7.69 \%)$ & $36(92.31 \%)$ & \\
\hline $41-50$ & $12(13.95 \%)$ & $74(86.05 \%)$ & 0.353 \\
\hline $51-60$ & $14(17.50 \%)$ & $66(82.50 \%)$ & \\
\hline
\end{tabular}

Table-VI. Prevalence of obstructive COPD according to age groups.

\begin{tabular}{|l|c|c|c|}
\hline & \multicolumn{2}{|c|}{ Obstructive COPD } & \multicolumn{1}{c|}{ P-Value } \\
\hline Gender & \multicolumn{1}{|c|}{ Yes } & No & \\
\hline Male & $22(16.06 \%)$ & $115(83.94 \%)$ & 0.265 \\
\hline Female & $07(10.29 \%)$ & $61(89.71 \%)$ & \\
\hline
\end{tabular}

Table-VII. Prevalence of obstructive COPD according to gender.

\begin{tabular}{|c|c|c|c|}
\hline \multirow{2}{*}{$\begin{array}{c}\begin{array}{c}\text { Duration of } \\
\text { Disease }\end{array} \\
\text { (years) }\end{array}$} & \multicolumn{2}{|c|}{ Obstructive COPD } & \multirow[t]{2}{*}{ P-Value } \\
\hline & Yes & No & \\
\hline$\leq 5$ years & $06(8.45 \%$ & 6) 65 (91.55\%) & 0.089 \\
\hline$>5$ years & $23\left(17.16^{\circ}\right.$ & \%) 111 (82.84\%) & \\
\hline \multicolumn{4}{|c|}{$\begin{array}{l}\text { Table-VIII. Prevalence of obstructive COPD with } \\
\text { respect to duration of smoking. }\end{array}$} \\
\hline & \multicolumn{2}{|c|}{ Obstructive COPD } & \multirow{2}{*}{ P-Value } \\
\hline BMI $\left(\mathbf{k g} / \mathbf{m}^{2}\right)$ & Yes & No & \\
\hline$\leq 27$ & 17 (11.49\%) & 131 (88.51\%) & 0.078 \\
\hline$>27$ & $12(21.05 \%)$ & 45 (78.95\%) & \\
\hline
\end{tabular}

Table-IX. Prevalence of obstructive COPD with respect to BMI. 


\begin{tabular}{|l|c|c|c|}
\hline & \multicolumn{2}{|c|}{ Obstructive COPD } & \multirow{2}{*}{ P-Value } \\
\hline Place of living & Yes & No & \\
\hline Rural & $13(10.08 \%)$ & $116(89.92 \%)$ & 0.029 \\
\hline Urban & $16(21.05 \%)$ & $60(78.95 \%)$ & \\
\hline
\end{tabular}

Table-X. Prevalence of obstructive COPD with respect to place of living.

\begin{tabular}{|l|c|c|c|}
\hline \multirow{2}{*}{$\begin{array}{c}\text { Socioeconomic } \\
\text { status }\end{array}$} & \multicolumn{2}{|c|}{ Obstructive COPD } & \multirow{2}{*}{ P-Value } \\
\hline Poor & $21(23.60 \%)$ & $68(76.40 \%)$ & \\
\hline Middle & $07(12.07 \%)$ & $51(87.93 \%)$ & 0.001 \\
\hline Upper & $01(1.72 \%)$ & $57(98.28 \%)$ & \\
\hline
\end{tabular}

Table-XI. Prevalence of obstructive COPD with respect to socioeconomic status.

\begin{tabular}{|l|c|c|c|}
\hline \multirow{2}{*}{$\begin{array}{c}\text { Education } \\
\text { Status }\end{array}$} & \multicolumn{2}{|c|}{ Obstructive COPD } & P-Value \\
\cline { 2 - 4 } \multicolumn{1}{|c|}{ Ylliterate } & $08(33.33 \%)$ & $16(66.67 \%)$ & \\
\hline Primary & $05(17.24 \%)$ & $24(82.76 \%)$ & \\
\hline Middle & $05(11.11 \%)$ & $40(88.89 \%)$ & 0.021 \\
\hline Matric & $08(15.69 \%)$ & $43(84.31 \%)$ & \\
\hline Graduate & $03(5.36 \%)$ & $53(94.64 \%)$ & \\
\hline
\end{tabular}

Table-XII. Prevalence of obstructive COPD with respect to education status.

\section{Pie Charts}

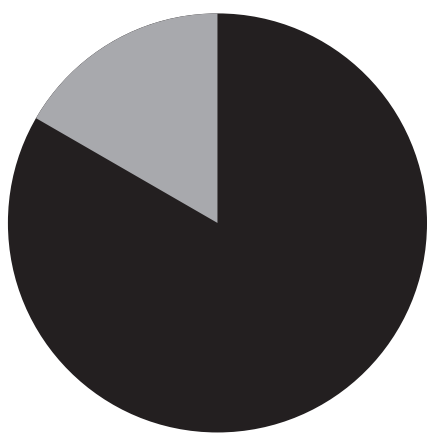

$57(27.80 \%)$

$148(72.20 \%)$

口 $<27 \mathrm{~kg} / \mathrm{m} 2$

$>27 \mathrm{~kg} / \mathrm{m} 2$

Figure-1. Gender frequency distribution $(n=205)$.

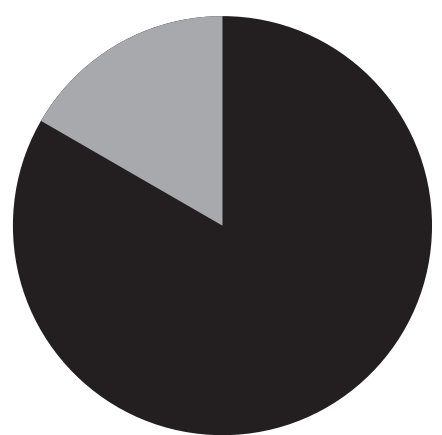

$57(27.80 \%)$

$148(72.20 \%)$

- $<27 \mathrm{~kg} / \mathrm{m} 2$

$>27 \mathrm{~kg} / \mathrm{m} 2$

Figure-2. BMI frequency distribution $(n=205)$.
Mean $\pm S D=26.21 \pm 5.39 \mathrm{~kg} / \mathrm{m}^{2}$

\section{DISCUSSION}

The ultimate proof which can be standardized in case of COPD is lacking in numerous previous researches. Important information from screening concentrates with the aim to apply spirometry to all smokers without considering the nearness of side effects is scant. Zielinski et $\mathrm{al}^{15}$ worked on more than 100,000 smokers, out of which the predominant cases of COPD were $20.03 \%$. Out of these, $64 \%$ of subjects had indications of cough mostly. Afterwards, a screening study showed that, amongst $13.3 \%$ of smokers who had COPD, 56\% had symptoms. ${ }^{16}$ These two researches demonstrate various smokers without side effects (WOS) having COPD. This information is significant in expanding the COPD sub diagnosis. ${ }^{17}$

Mean age of $47.78 \pm 4.90$ years was calculated between 30 to 60 age group ranges. Majority (86$41.95 \%$ ) belong to 41 to 50 years of age. Among 205 patients, majority (137-66.83\%) were males and rest (68-33.17\%) were females. Frequency of obstructive pattern on spirometry was found in $29(14.15 \%)$ patients in asymptomatic chronic smokers. A former study showed COPD incidence of $21.5 \%$ in asymptomatic smokers. ${ }^{12}$ Another study in $\mathrm{CMH}$ Rawalpindi Pakistan demonstrated COPD prevalence of $8.5 \% .{ }^{13}$

Another study ${ }^{21}$ showed that if smokers are treated with bronchodilators, advances are perceived in air route function and lung volume. It was found in a former research that out of nearly 1300 smokers with COPD, $14.3 \%$ had no symptoms. Similar to this, data from another earlier study ${ }^{22}$ showed that the lack of respiratory symptoms enhanced the possibility of undiagnosed COPD. Consequently, our results demonstrated that the increased level of FEV1 anticipated COPD in asymptomatic smokers. ${ }^{23}$

A previous study shows the association between smoking habits and lung function changes. ${ }^{13}$ Thus, this study concluded that cigarette smoking is undoubtedly associated with a decrease in pulmonary function. ${ }^{24}$ This research promotes 
the premature practice of PFTs in asymptomatic smokers.

On the off chance that smoking causes recognizable changes in little respiration route bore at such an younger age, it will likewise cause intense variations in little respiration routes. It is recommended that more than $14 \%$ of overwhelming smokers create respiration route impediment because of variations from the norm in respiration routes with under $2 \mathrm{~mm}$ inside measurement. Respiration route check is related with a constant provocative procedure in the bronchioles, as appeared by past examinations. Respiration route choking in COPD and decrease in PFTs are believed to be permanent. ${ }^{20}$

An examination on nearly 6000 subjects was done to inspect the impact of smoking on FEV1 with spirometry. Subjects were observed with a background marked by smoking for a long time persistently, $38 \%$ of smokers had a FEV1 under $60 \%$ of the anticipated ordinary worth contrasted and $10 \%$ of supported weaklings. These discoveries fortify our perspective on the advantages of leading PFTs prompt.

Clennell S et al, in 2008 led a partner concentrate on 3286 subjects, to examine the lung work in non-smokers, smokers and previous smokers. The examination presumed that the pace of lung work decrease of the smokers was quicker than others. The examination established no critical distinction in pace of decrease in lung work in previous smokers once contrasted with the individuals who had never smoked. ${ }^{25}$

An on-going report directed to discover a distinction in PFT values. It demonstrated a decline in lung function proportion with an expansion in the quantity of long stretches of smoking. At each age gathering, smokers bunch had decreased PFTs.

Nighute $\mathrm{N}$ et al ${ }^{26}$ inferred that a huge decrease was observed in the mean qualities of lung functions in smokers. Another study in 2014 demonstrated that smokers utilizing spirometry help distinguish few patients with respiration route block who are at high hazard for COPD.

In an on-going report, the general weight of COPD is probably going to diminish by early identification of COPD utilizing spirometry with smoking record of more than 200.

\section{CONCLUSION}

It was concluded that there is increased frequency of obstructive COPD on spirometry in asymptomatic chronic smokers. Hence we recommend that there should be some education programs with efforts both from personal and national levels to avoid smoking and also early preventive measures can be taken in this particular population.

Copyright@ 15 Sep, 2020.

\section{REFERENCES}

1. Aaron SD, Vandemheen $\mathrm{KL}$, Ramsay T. Multi analyte profiling and variability of inflammatory markers in blood and induced sputum in patients with stable COPD. Respir Res. 2010; 11:41.

2. Abrams TE, Vaughan-Sarrazin M, Fan VS, Kaboli PJ. Geographic isolation and the risk for chronic obstructive pulmonary disease-related mortality: A cohort study. Ann Intern Med. 2011 Jul 19. 155(2):80-6.

3. Adams PF, Barnes PM, Vickerie JL. Summary health statistics for the U.S. population: National Health Interview Survey, 2007. Vital Health Stat 10. 2008 Nov. 1-104.

4. Albert RK, Connett J, Bailey WC, et al. Azithromycin for prevention of exacerbations of COPD. $\mathrm{N}$ Engl $\mathrm{J}$ Med. 2011 Aug 25. 365(8):689-98.

5. Andersen ZJ, Hvidberg M, Jensen SS, Ketzel M, Loft $\mathrm{S}$, Sorensen $\mathrm{M}$, et al. Chronic obstructive pulmonary disease and long-term exposure to traffic-related air pollution: A cohort study. Am J Respir Crit Care Med. 2011 Feb 15. 183(4):455-61.

6. Anoro Ellipta (umeclidinium and vilanterol inhalation powder) [package insert]. Research Triangle Park, NC: Glaxo Smith Kline. 2013. Available at.

7. Barclay L. COPD linked to cognitive impairment and memory loss. Medscape Medical News. December 12, 2013. 
8. Barthwal MS, Singh S, Early detection of chronic obstructive pulmonary disease in asymptomatic smokers using spirometry. J Assoc Physicians India 2014;16:238-42.

9. Beasley V, Joshi PV, Singanayagam A, Molyneaux PL, Johnston SL, Mallia P. Lung microbiology and exacerbations in COPD. Intl J COPD. 2012;7:555 -69

10. Beasley V, Joshi PV, Singanayagam A, Molyneaux PL, Johnston SL, Mallia P. Lung microbiology and exacerbations in COPD. Intl J COPD. 2012;7:555-69

11. Bednarek JZM, Early detection of COPD in a high risk population using spirometric screening Chest 2001 119:731-36.

12. Belman MJ, Botnick WC, Shin JW. Inhaled bronchodilators reduce dynamic hyperinflation during exercise in patients with chronic obstructive pulmonary disease. Am J Respir Crit Care Med. 1996 Mar. 153(3):967-75.

13. Boskabady $\mathrm{MH}$, Dehghani $\mathrm{H}$, Esmaeilzadeh $\mathrm{M}$, Pulmonary function tests and their reversibility in smokers Tanaffos 2003 2(8):23-30.

14. Boskabady $\mathrm{MH}$, Mahmoodinia $\mathrm{M}$, Boskabady $\mathrm{M}$, Heydari GR, Pulmonary function tests and respiratory symptoms among smokers in the city of mashhad (north east of Iran) Rev Port Pneumol 2011 17(5):199204.

15. Zielinski J, Bednarek M, Goŕecka D. Increasing COPD awareness. Eur Respir J. 2006; 27(4):833-852.

16. Vincken W, van Noord JA, Greefhorst AP, Bantje TA, Kesten S, Korducki L, et al. Improved health outcomes in patients with COPD during 1 yr's treatment with tiotropium. Eur Respir J. 2002 Feb. 19(2):209-16.

17. Vogelmeier C, Hederer B, Glaab T, Schmidt H, Ruttenvan Molken MP, Beeh KM, et al. Tiotropium versus salmeterol for the prevention of exacerbations of COPD. N Engl J Med. 2011 Mar 24. 364(12):1093-103.
18. Vos T, Flaxman AD, Naghavi M, Lozano R, Michaud $\mathrm{C}$, Ezzati $\mathrm{M}$, et al. Years lived with disability (YLDs) for 1160 sequelae of 289 diseases and injuries 1990 -2010: A systematic analysis for the global burden of disease study 2010. Lancet. 2012; 380(9859):2163-96.

19. Walters JA, Walters EH, Wood-Baker R. Oral corticosteroids for stable chronic obstructive pulmonary disease. Cochrane Database Syst Rev. 2005 Jul 20. CD005374.

20. O'Donnell DE, Laveneziana P, Ora J, Webb KA, Lam YM, Ofir D. Evaluation of acute bronchodilator reversibility in patients with symptoms of GOLD stage I COPD. Thorax. 2009; 64(3):216-223.

21. Wood S. Inhaled Long-Acting Bronchodilators in COPD Flagged Again for CV Hazard. Medscape Medical News. Available at http://www.medscape.com/ viewarticle/804441. Accessed: June 4, 2013.

22. Walters JA, Tan DJ, White CJ, Gibson PG, Wood-Baker $\mathrm{R}$, Walters EH. Systemic corticosteroids for acute exacerbations of chronic obstructive pulmonary disease. Cochrane Database of Systematic Reviews. 2014(9).

23. Yang SC, Relationship between smoking habits and lung function changes with conventional $\mathrm{J}$ Formos Med Assoc 1993 92(4):S225-31.

24. Clennell S, Kuh D, Guralnik JM, Patel KV, Mishra GD, Characterization of smoking behaviour across the life course and its impact on decline in lung function and all-cause mortality. J Epidemiol Community Health 2008;62(12):1051-56.

25. Nighute $S$, Awari A, A study of the pulmonary function test among smokers and non-smokers in a rural area of Gujarat. J Clin Diagn Res 2011;5(6):1151-53.

26. Wisnivesky J, Skloot G, Rundle A, Revenson TA, Neugut $A$, Spirometry screening for airway obstruction in asymptomatic smokers Aust Fam Physician 2014;43(7):463-67. 


\begin{tabular}{|c|c|c|c|}
\hline \multicolumn{4}{|c|}{ AUTHORSHIP AND CONTRIBUTION DECLARATION } \\
\hline Sr. \# & Author(s) Full Name & Contribution to the paper & Author(s) Signature \\
\hline 1 & Zaid Umer & $\begin{array}{l}\text { Conception and design of work, } \\
\text { resutls compiling. }\end{array}$ & \\
\hline 3 & Muhammad Waseem & Supervision and revising it critically & \\
\hline 4 & Nauman Aziz & $\begin{array}{l}\text { for important intellectual content. } \\
\text { Final approval of the version to be } \\
\text { published. }\end{array}$ & \\
\hline 5 & Hafiza Swaiba Afzal & Help in biostatics and data & \\
\hline 6 & & Analysis and interpretation & $\ldots x^{+}$ \\
\hline
\end{tabular}

